\title{
Village Fund Policy Implementation Strategy in Sumedang Regency
}

\author{
Restu Widyo Sasongko', Ummu Salamah², Ikin Sodikin ${ }^{3}$ \\ 1,2,3Universitas Pasundan, Bandung, Indonesia \\ Email: restu widyo@ipdn.ac.id
}

\begin{abstract}
According to its goals, the Village Fund Policy is successful if it improves the health of rural people and promotes equitable village growth. The aim of this analysis is to investigate and evaluate the factors that contribute to the successful implementation of the Village Fund policy in Sumedang Regency, as well as the strategies that can be implemented. The researchers used observational research techniques in conjunction with a case study approach. This approach was selected in order to gather reliable data for the purpose of identifying important factors affecting the Village Fund strategy. The findings indicate that a variety of factors contribute to the policy's progress in Sumedang Regency, including the affected priorities, the benefits provided, the required degree of improvement, the role of policymakers and program implementers, the resources deployed, and the power and strategies of the actors involved. Institutional characteristics, as well as conformity and responsiveness. However, it is well established that the resource element has been underutilized, with the village relying entirely on funding sources from the Village Budget, the Village Fund Allocation, and other profit-sharing funds for government administration, growth, and community empowerment.
\end{abstract}

Keywords: Strategy, Policy Implementation, Village Fund.

\section{A. INTRODUCTION}

The village is the smallest legal community unit that exists and develops in tandem with Indonesian society's growth (Chasanah et al., 2017). At the same time, this reality establishes the village as an inseparable unit, whose presence is recognised throughout Indonesia's history and growth (Adisasmita, 2013). A village is a government body that has been granted the right to customary sovereignty in order to function as a legal entity. At the same time, the sub-district is an administrative government body that serves as an extension of the district/city government in the central kelurahan (Aziz, 2016). Simultaneously, a village within a defined geographical area as a legal community unit (customary) has the authority to administer and handle local community affairs in accordance with its origins (Nurcholis, 2011).

As a government unit and as a legal community unit, the existence of villages is essential in state administration (Firdaus, 2011). As a government unit, the village is the front liner in providing services to the community. As a legal community unit, the village is a solid foundation for the Indonesian nation's social system and a strong foundation for developing a political, economic, socio-cultural, and defense and security system (Jabir, 2018). Given the breadth and diversity of community units, other names for villages in several areas are known, such as Gampong in 
Aceh, Nagari in West Sumatra, Kepenghuluan in Riau, and Kampung Papua (Sasongko, 2019).

According to Law No. 6 of 2014 and its derivative regulations, villages receive revenue from original village income, revenue sharing from local taxes and district/city retribution, a portion of the central and regional financial balancing funds received by districts/cities, budget allocations from APBN, financial assistance from the provincial APBD and district/city APBD, as well as $g$ (Widodo, 2016). This source of village revenue is used to finance all village-level authorities. These funds are used to assist villages in carrying out village authority functions such as governance, growth, community empowerment, and society (Utama et al., 2019).

The Village Fund is one of the village's revenue streams, receiving funding allocations from the State Revenue and Expenditure Budget (APBN) (Nafidah \& Suryaningtyas, 2016). In accordance with the terms of Law No. 6 of 2014, the Village Fund is used to fund the entire village authority in accordance with the village's needs and goals. Given that the Village Fund is derived from the APBN, the government has the authority to establish goals for the benefit of Village Funds to promote development projects and village community empowerment. Naturally, this prioritization would adhere to the village's authority (Tangkumahat et al., 2017). Government Regulation Number 60 of 2014 was enacted in response to the provision of Law Number 6 of 2014, which was subsequently revised by Government Regulation Number 8 of 2016 covering Village Funds Sourced from the State Revenue and Expenditure Budget.

The Central Government budgets a sizable Village Fund per year. The Village Fund received a budget of IDR 20.7 trillion in 2015, with an average allocation of IDR 280 million per village. The Village Fund increased to Rp. 46.98 trillion in 2016, with an average of Rp. 628 million per area, and to Rp. 60 trillion in 2017, with an average of Rp. 800 million per village. Following the goals of village growth set out in Law No. 6 of 2014, namely enhancing the health of rural people, the quality of human life, and poverty elimination, the distribution of Village Funds takes the degree of poverty into account further (Sari \& Abdullah, 2017).

Regarding Village Funds distributed in Sumedang Regency, West Java Province, the applicable provisions are the same as those for other regions. From 2015 to 2018, there has been an increase in the amount of Village Fund allocated to Sumedang Regency. The district, which has 270 villages, received Village Funds of Rp. 77 billion in 2015, increased to Rp. 173 billion in 2016 and increased again to 217.27 billion in 2017. In 2018, the Village Fund allocated for Sumedang Regency decreased from the year previously, which was IDR 192.69 billion. Compared with the number of villages as a whole, until 2018, every village in Sumedang District received Village Funds of more than IDR 2.4 billion.

According to the amount of Village Funds allocated, there should be positive changes in the rural communities of Sumedang Regency's quality of life, especially in terms of economic welfare. In other words, the rise in the village community's standard of living is a sign of the policy's effective adoption in Sumedang Regency. 
As far as the researcher observes, it has been caught in the phenomenon that Village Funds in Sumedang Regency focuses more on infrastructure development. This is no different from other villages in Indonesia. Village communities who are "thirsty" for the availability of adequate infrastructure are a prominent factor in the tendency to use Village Funds as a source of funding for the development or improvement of village infrastructure (Abidin, 2015). One might argue that the percentage of Village Funds allocated to neighborhood empowerment projects is very high, and capital for productive economic activities, such as Village-Owned Enterprises, is still minimal compared to those used for building village environmental facilities and infrastructure (Rahayu, 2017).

From a political and administrative standpoint, as proposed by Grindle in (Nugroho 2014), the Village Fund strategy formulation undoubtedly has priorities, is informed by a variety of considerations, including the procedure's substance and success background, and produces outcomes in the form of impacts and improvements on village populations. According to Satria Utama, Khasan Effendy, Ngadisah, and Lalu Wildan's report, the Village Fund scheme has not yet been implemented in a manner consistent with the intention of achieving village independence. Village Fund program adoption faces challenges in terms of preparation materials, oversight, low-quality human capital, enforcement, deliberative procedures, village heads' and village officials' conduct, social system instability, ambiguous indices of independence effects, and authority transparency (Utama et al., 2019 ).

Research with similar results was carried out by Santoso (2018) using the Grindle (1980) model as a basis, concluding that the implementation of the Village Fund policy has not been maximal. This is indicated by at least 3 (three) factual conditions, namely (1) that the distribution of Village Funds has been delayed due to the village party not being able to complete the disbursement requirements according to the time specified; (2) more than 90 percent of the Village Fund is used for physical development; (3) reporting on the use of Village Funds that is always late or does not comply with the provisions. This condition results from obstacles concerning the content (content) of the policy and the context of the implementation of the policy.

This research is intended to study and analyze the problems of implementing the Village Fund policy in the Sumedang Regency. The research is also designed to research and explore strategies to implement the Village Fund policy in Sumedang Regency can run effectively. This research is expected to be a media and learning resource as well as the development of public administration science and public policy and provide information and contribution of thoughts in the form of accurate recommendations for policy stakeholders at the regional level, especially in Sumedang Regency, concerning the implementation of the Village Fund policy. 


\section{B. METHOD}

This study employs a qualitative approach to conduct studies on natural or naturalistic object environments. The researcher is a critical tool, data interpretation is inductive, and study findings place a premium on context over generalization (Sugiyono, 2014). Qualitative research methods are intensive; researchers spend an extended period of time in the field, meticulously log what occurs, do reflective analysis of different records discovered in the region, and write comprehensive research papers (Sugiyono, 2014).

The analysis will take the form of a case study, a systematic examination of a single setting or occurrence (Idrus, 2016), or an approach that examines a problem and its context using data from a variety of sources (Sarosa, 2012). As a result, the researcher sought to perform an in-depth review of one of the study's analysis units, including the implementation of the Village Fund policy.

\section{RESULT AND DISCUSSION}

Numerous factors, including the village's status as the policy's implementing topic and goal, will impact the success and outcomes of the Village Fund policy's implementation. Some elements support or otherwise hinder. These factors can come from the internal environment, and they can also come from the external environment. Therefore, the Village Fund policy implementation strategy also needs to consider and involve these internal and external factors.

The Village Fund Policy has been effectively implemented for 5 (five) years, namely since 2015. Every year, the government conducts evaluations and various improvement efforts to run optimally to advance rural areas. The implementation of the Village Fund policy deserves to be continued. However, it must be accompanied by a refinement of the strategy given the dynamic development of social, economic, and political conditions.

The SWOT analysis in this study is used to determine external factors that can become threats and various things that can become opportunities for successfully implementing the Village Fund policy. Furthermore, the internal factors that are the strengths and weaknesses of the policy's performance can also be identified. With the SWOT analysis, the formulation of a Village Fund policy implementation strategy adaptive to existing conditions will be found so that the policy's objectives can be realized as expected.

Internal Factors for Village Fund Policy Implementation:

\section{Strengths}

a. Extensive agricultural land

b. Availability of village government facilities and infrastructure

c. The existence of an organizational structure and work structure for the village government apparatus

d. The population and workforce continues to grow

e. Village government compliance with statutory provisions, especially those relating to villages and Village Funds. 


\section{Weakness}
a. There are still high cases of stunting
b. Weak professionalism of village officials
c. Lack of training for village officials in applying e-Government (for example, through Siskeudes and e-SAKIP)
d. Not optimal management of village treasury lands as a source of income.
e. The village government's dominance, especially the Village Head, in government and village development.
External Factors Implementation of village fund policies includes:

\section{Opportunities}
a. Legislations related to villages and Village Funds as a normative basis.
b. Regional development
c. National and regional political conditions
d. Village assistant
e. Technological development.

\section{Threats}
a. Changing laws and regulations
b. Delay in submitting reports
c. Delay in distributing village funds from districts to villages
d. Too many parties oversee the management of the Village Fund
e. There was a disaster.

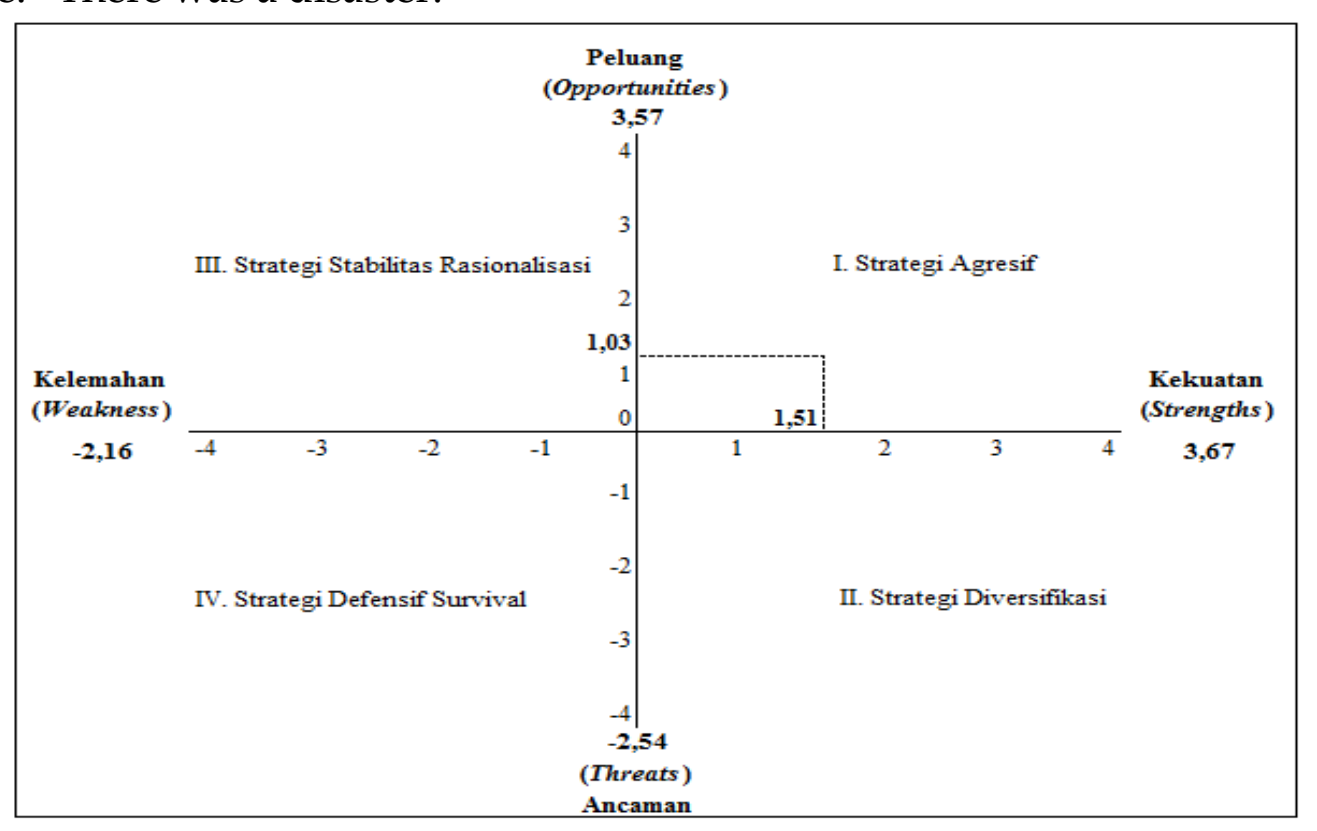

\section{Figure 1 Position Map for Village Fund Policy Implementation Strategy in Sumedang Regency}

The SWOT analysis results show that the strategic position for implementing Village Fund policies in Sumedang District, especially in villages that are the objects of research, is an aggressive strategy to support policy implementation. This position indicates that the right strategic choice emphasizes using strength to take advantage of opportunities. 
Following the results of the calculation of the SWOT analysis (Fig. 1), where the map of the position of the Village Fund policy implementation strategy is in quadrant I, the emphasis is on the S-O strategy. In this regard, several strategies can be explained to optimize the implementation of the Village Fund policy in Sumedang Regency as follows:

1. Establish consistent regulations and bureaucracy related to Village Fund policies. On the one hand, the existence of these regulations is essential and valuable so that the distribution and use of Village Funds are appropriate and right on target, and safe from fraud or corruption. However, on the other hand, too many regulations and tend to fluctuate can confuse policy implementers, especially at the lowest level, namely the village government. Another result delays in the preparation and delivery of the APBDes and reporting of the use of Village Funds by the village government. The tip of the delay in reporting is the delay in disbursing the Village Fund and, of course, the realization of the program or activity that has been planned. Such conditions can be overcome through several steps, including:

a. Establish a single regulation as a guideline for the implementation of distribution and priority for the use of Village Funds

b. Simplify the bureaucracy of Village Fund disbursement.

2. Optimizing local resources in the use of Village Funds.

a. Human capital use (HR). The utilization of human capital in the Village Fund's operations requires the Village Fund's cash-intensive policy. Cash for work is a productive practice that empowers rural populations, especially the vulnerable, by prioritizing local services, labor, and technology in order to maximize wages, buying power, and poverty reduction while still supporting the decline-stunting trend. The Village Fund's cash-for-work program is projected to recruit a substantial number of jobs everyday and regularly, with a direct pay structure for the workforce involved, in order to boost people's purchasing power, increase economic prosperity, and improve the health of rural residents.

b. Utilization of natural resources. Natural resources in the village are considered very abundant to support development and community empowerment programs. However, the facts on the ground show that these tremendous natural resources have not been used optimally to support the implementation of Village Fund policies and a source of village income (PADesa).

3. Optimizing information technology-based work facilities in the management of Village Funds. In recent decades, information technology has penetrated all areas of life, including government administration. The use of information technology in government or from now on known as e-Government is a form of Utilization of information and communication technology (ICT) to increase efficiency, effectiveness, transparency, and accountability to improve the quality of government administration. The use of information and 
communication technology is also very feasible to be used as a strategy to optimize the implementation of Village Fund policies. Especially in conditions when the Covid-19 outbreak was prolonged, several hundred million Indonesians were connected to the internet, even in remote villages. Even before the Covid-19 pandemic, information and communication technology had penetrated people's lives. Thus, it would be appropriate for this technology to be involved in managing the Village Fund. One tangible form of utilizing information and communication technology is the creation of village websites. In this connection, the capacity of village officials in the mastery of information and communication technology needs to be improved. The Village Fund Policy, which is one of the concrete forms of the implementation of Law Number 6 of 2014 concerning Villages, has been implemented since 2015. Throughout the five years of its performance, there has been an increase in the number of funds disbursed, accompanied by various improvements in the procedures for its implementation. As a policy that directly touches the public, especially those in rural areas, the performance of the Village Fund policy must adapt to the development of very dynamic conditions. Therefore, an appropriate strategy is needed to effectively implement the Village Fund policy and produce the expected positive impact.

Based on the results of research on 9 (nine) villages in the Sumedang Regency, it can be said that the Village Fund policy is implemented in a uniform pattern. This cannot be separated from the territorial conditions and the social-cultural background, which are almost identical from one village to another. In addition, the existence of the PDTT Village Ministerial Regulation regarding the priority for the use of Village Funds as well as the Sumedang Regent Regulation concerning the procedures for the use, distribution, reporting, guidance, supervision, and imposition of administrative sanctions also constitutes a kind of "instruction" indirectly for the uniformity. The village party tended to be limited to planning and compiling the program of activities and the necessary budget but did not dare to take the initiative too much in the use of funds for fear of being perceived as misappropriating or acting beyond their authority. As a result, if there is a delay in the disbursement of the Village Fund, the programs that the village has budgeted will also be late in implementing.

Regarding the low level of community participation, it can be said that this phenomenon occurred in all the villages studied. Village meetings, which are relied on as a forum for planning programs or activities in implementing Village Fund policies, do not go as expected. The village government element (village head) is still dominant in designing these programs/activities. Never mind the village community; even the leaders of the RT or RW heads do not know anything about village deliberations for the Village Fund or programs/activities that are planned and will be implemented to use the Village Fund. Public participation, it must be admitted, is only limited to enthusiasm for the proliferation of infrastructure 
development such as repairing waterways, concreting village roads or farm roads, and so on.

The problem most felt by the village was the delay in disbursing the Village Fund. As far as researchers have observed, there are several causes for this delay. First, the completion of the village verification process was delayed from the original schedule due to the large number of villages that had to be verified. Second, the process of disbursing Village Funds is carried out from the State General Treasury Account (RKUN) first to the Regional Treasury General Account (RKUD), then transferred to the Village Treasury Account (RKD). Third, delays in enacting a Regent Regulation regulating the processes and specifics about the volume and usage of the Village Fund in each village. Fourth, the village's delay in sending reports to the District Government in the form of the Village Revenue and Expenditure Budget (APBdesa) and the Village Medium-Term Development Plan (RPJMDes), as well as reports on the Village Fund's use in previous stages.

The government's strategy to overcome the delays in the Village Funds' distribution and disbursement is to cut bureaucracy. Based on the Minister of Finance Regulation Number 205 / PMK.07 / 2019, which has been amended for the third time by the Minister of Finance Regulation Number 156 / PMK.07 / 2020, Village Fund transfers are carried out directly from RKUN to RKD. However, the details of the amount of the Village Fund for each village are still being determined through a Regent Regulation. Thus, whether the Village Fund is disbursed late or not depends on the schedule's accuracy for the Regent Regulation's stipulation.

Another technique for optimizing Village Fund use is the Village Fund Cashfor-Work (PKT-DD) program. This policy has been applied in phases since 2018 but has not been fully implemented in all villages. According to the observations made in the nine (nine) villages in Sumedang District that were studied, only two (two) villages, namely Gudang Village and Jatisari Village Tanjungsari District, introduced the PKT-DD system .

The following strategy implemented in implementing the Village Fund policy is related to the conditions of force majeure in the Covid-19 outbreak, which is so widespread. The strategy referred to is to use a portion of the Village Fund, which is between 25-35 percent received by each village, as a social safety net in the form of Village Fund Direct Cash Assistance (BLT-DD). BLT-DD was given to poor people affected by the Covid-19 pandemic who were not participants of the Family Hope Program (PKH). Regarding the number and who are the recipients of BLT-DD, it falls under the authority of the village government. It is decided through a Special Village Deliberation, which also involves the BPD and is stipulated in a Village Head Decree form.

Cash for Work Village Fund (PKT-DD) is a development activity that focuses on rural areas, especially the poor and disadvantaged, and is active by emphasizing the use of local services, labour, and technology to generate additional revenue, raise buying power, and alleviate poverty while also contributing to stunting rate reduction. PKT-primary DD's priorities are those who are not working 
(unemployed), those who are underemployed, and the sick. For unemployed people, priority is given to unemployed residents, residents who have been laid off (PHK), and residents looking for work. For underemployed people, priority for activities is given to residents who work below regular working hours (less than 35 hours a week) and residents who are still looking for work or are still willing to accept employment. As for the poor and vulnerable, priority is given to the unemployed workforce or below the poverty line.

The rapid development of technology encourages all forms of human activity to be done digitally in every area of life-no exception for government activities, including village administration. Therefore, mastery of information and communication technology is so essential for government stakeholders. In various conditions, digital communication is an essential means of conveying multiple kinds of information needed by society. Given that technological devices such as cellphones, computers, and the like have become commonplace, it is better if all of them are maximized to achieve benefits. Not solely as unproductive tertiary goods. With good techniques and habits, digital communication can also be used to foster reading interest and a culture of reading carefully and thoroughly.

In essence, the use of ICT within the framework of implementing the Village Fund policy has been implemented considering that the extent of the internet network has been so massive and has reached rural areas. It can be said that many people know and use the internet, even though it is limited to using cellular phones.

Referring to the research findings as described above, it can be said that several factors should be considered in the implementation of a policy apart from the elements as stated by Merille S. Grindle (1980). Several factors that can influence the policy implementation strategy include:

1. The social culture factor of the community is the target group for implementation. In the case of the Village Fund policy's performance, the village communities' social culture in Sumedang Regency, which is relatively homogeneous, has resulted in a uniform implementation pattern and tends to be up to the bottom.

2. Force majeure conditions as a result of global disasters such as the Covid-19 pandemic. In the case of the implementation of the Village Fund policy, there have been changes to regulations regarding the priority for the use of the Village Fund. In other words, a policy must be modified in such a way when it is implemented to suit existing conditions.

3. There are factors for advancing science and technology (science and technology), mainly information and communication technology (ICT). As it is known, in the last decade, ICT has progressed very rapidly, and its use is very massive among the community and even in rural areas. The advancement of ICT can be used as a supporting capacity for policy implementation, at least to facilitate the socialization of policies. 


\section{CONCLUSION}

Strategies that can be developed and implemented in implementing Village Fund policies in Sumedang Regency include establishing consistent regulations and bureaucracy related to Village Fund policies. This strategy is essential to implement so that there are no overlaps and changes to rules governing the management of Village Funds and delays in the distribution and disbursement of Village Funds. This strategy can be implemented, among others, through establishing a single regulation as a guide for the implementation of allocation and prioritization for the use of Village Funds and simplifying the bureaucracy of Village Fund disbursements. Optimizing local resources in the use of the Village Fund. This strategy can be implemented to utilize the human resources (HR) of indigenous villagers through the cash-for-work Village Fund (PKT-DD) scheme. The next step that is no less important is to optimize the Utilization of village natural resources, which are considered very abundant to support development programs and community empowerment and a source of village income (PADesa). Utilizing natural resources, such as village treasury lands, is very feasible to implement to encourage villages to become more independent. Optimizing information technology-based work facilities in the management of Village Funds. This strategy needs to be carried out considering the rapid development of information technology that has been utilized in government administration so that it can also be used as an instrument to support the implementation of Village Fund policies. One tangible form of information and communication technology is the online Village Fund reporting system and the creation of a village website. In this connection, the capacity of village officials in the mastery of information and communication technology needs to be improved.

\section{REFERENCES}

1. Abidin, M. Z. (2015). Tinjauan Atas Pelaksanaan Keuangan Desa dalam Mendukung Kebijakan Dana Desa. Jurnal Ekonomi \& Kebijakan Publik, 6(1), 61-76.

2. Adisasmita, R. (2013). Pembangunan Perdesaan: Pendekatan Partisipatif, Tipologi, Strategi, Konsep Desa Pusat Pertumbuhan. Yogyakarta: Graha Ilmu.

3. Aziz, N. L. L. (2016). Otonomi Desa dan Efektivitas Dana Desa. Jurnal Penelitian Politik, 13(2), 193-211.

4. Chasanah, K., Rosyadi, S., \& Kurniasih, D. (2017). Implementasi Kebijakan Dana Desa. The Indonesian Journal of Public Administration (IJPA), 3(2), 12-32.

5. Firdaus, E. (2011). Badan Permusyawaratan Desa dalam Tiga Periode Pemerintahan di Indonesia. Jurnal Ilmu Hukum, 2(2).

6. Grindle, M. S. (1980). Politics and Policy Implementation in the Third World. New Jersey: Princeton University Press.

7. Idrus, M. (2016). Metode Peneltian Ilmu Sosial Pendekatan Kualitatif dan Kuantitatif. Jakarta: Penerbit Erlangga. 
8. Jabir, H. (2018). Peran Tenaga Pendamping Desa Pada Pelaksanaan Program Pembagunan Dan Pemberdayaan Masyarakat Di Desa Watu Kecamatan Marioriwawo Kabupaten Soppeng (Doctoral Dissertation, Universitas Negeri Makassar).

9. Nafidah, L. N., \& Suryaningtyas, M. (2016). Akuntabilitas Pengelolaan Alokasi Dana Desa Dalam Upaya Meningkatkan Pembangunan Dan Pemberdayaan Masyarakat. BISNIS: Jurnal Bisnis dan Manajemen Islam, 3(1), 214-239.

10. Nugroho, R. (2014). Public Policy. Jakarta: Elexmedia Komputiondo.

11. Nurcholis, H. (2011). Pertumbuhan dan Penyelenggaraan Pemerintahan Desa, Jakarta: Erlangga.

12. Rahayu, D. (2017). Strategi Pengelolaan Dana Desa untuk Meningkatkan Kesejahteraan Masyarakat Desa Kalikayen Kabupaten Semarang. Economics Development Analysis Journal, 6(2), 107-116.

13. Santoso, R. S. (2018). Implementasi Kebijakan Dana Desa di Kabupaten Semarang (Studi Kasus Di Desa Randugunting, Kecamatan Bergas). Journal of Public Policy and Management Review, 7(2), 649-664.

14. Sari, I. M., \& Abdullah, M. F. (2017). Analisis Ekonomi Kebijakan Dana Desa Terhadap Kemiskinan Desa Di Kabupaten Tulungagung. Jurnal Ekonomi Pembangunan, 15(1), 34-49.

15. Sarosa, S. (2012). Penelitian Kualitatif Dasar-Dasar. Jakarta: Indeks.

16. Sasongko, R. W. (2019). Kebijakan Alokasi Dana Desa (Add) Dalam Rangka Mengoptimalkan Pembangunan Desa. Visioner: Jurnal Pemerintahan Daerah di Indonesia, 11(4), 455-462.

17. Sugiyono, (2014). Memahami Penelitian Kualitatif. Bandung: Alfabeta.

18. Tangkumahat, F. V., Panelewen, V. V., \& Mirah, A. D. (2017). Dampak Program Dana Desa Terhadap Peningkatan Pembangunan Dan Ekonomi Di Kecamatan Pineleng Kabupaten Minahas. Agri-Sosioekonomi, 13(2A), 335-342.

19. Utama, L. S., Effendy, K., Ngadisah, N., \& Wildan, L. (2019). Analisis Implementasi Kebijakan Dana Desa Dalam Meningkatkan Kemandirian Desa di Kabupaten Lombok Tengah Provinsi NTB. Media Bina Ilmiah, 14(1), 1887-1902.

20. Widodo, I. S. (2016). Badan Usaha Milik Desa Sebagai Salah Satu Alternatif Sumber Pendapatan Desa Berdasarkan Undang-Undang Nomor 6 Tahun 2014 Tentang Desa. Jurnal Panorama Hukum, 1(1), 1-14. 